\title{
Interaction between Environment, Economy, Society and Health in the Concept of Environmental Health: Studies on Peatland Communities
}

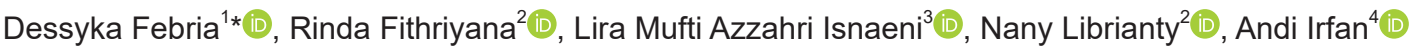 \\ ${ }^{1}$ Department of Nursing, Faculty of Health Science, Universitas Pahlawan Tuanku Tambusai, Riau, Indonesia; ${ }^{2}$ Department of \\ Entrepreneurship, Faculty of Economics and Business, Universitas Pahlawan Tuanku Tambusai, Riau, Indonesia; ${ }^{3}$ Department \\ of Public Health, Faculty of Health Science, Universitas Pahlawan Tuanku Tambusai, Riau, Indonesia; ${ }^{4}$ Department of \\ Accountancy, Faculty of Economics and Social Science, Universitas Islam Negeri Sultan Syarif Kasim, Riau, Indonesia
}

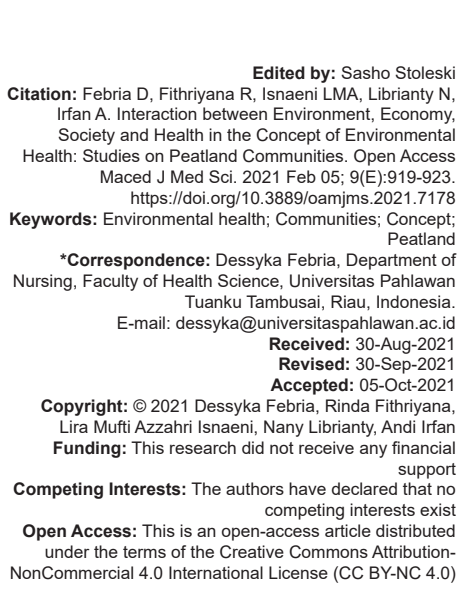

\section{Abstract}

BACKGROUND: The current environmental issue that concerns us all is the use of peatland for oil palm plantations. This damages the peatland ecosystem, even though peatland are very important in the hydrological system of the downstream area of a watershed. One of the impacts of the destruction of the peat ecosystem is the occurrence of flooding in the downstream watershed. In addition, if forest and peatland fires occur, it will cause CO2 emissions, thereby disrupting public health.

AIM: The purpose of this research is to develop the concept of environmental health. The focus of this research is improving environmental health in communities on peatlands.

METHODS: The research method used was qualitative where data collection was done through interviews, observation, and documentation.

RESULTS: The findings of this study are that the research location is dominated by oil palm plantations which have a negative impact on public health.

CONCLUSION: Based on these findings, the development of the concept of environmental health is the interaction between the environment, economy, society and health to improve the quality of life.

\section{Introduction}

Environmental health science is related to the natural and social environment which, in turn, affects human health. This reflects the complex and heterogeneous character of the environmental health structure. Many sciences have made special contributions to environmental health analysis, including environmental hygiene, toxicology and epidemiology, natural sciences, economics, and social sciences [1]. The environmental issue that is currently the main concern is the use of peatlands for oil palm plantations. In this case, the most important thing for society is to improve the family economy. But unfortunately, they do not pay attention to the impact that will be caused by the use of peatlands for oil palm plantations in the future. The emergence of this problem is caused by human behavior that has an impact on their own lives. There have been many forest fires in Indonesia. For example, in 2015, there was a forest fire covering an area of 2.6 million hectares and 49.2 million hectares in 2016 .
Most of the forest fires occurred in the provinces of Riau, South Sumatra, Jambi, Central Kalimantan, West Kalimantan, and Papua where $30 \%$ of the fires occur on peatland. Fires on peatlands have a much higher impact than fires on mineral soil due to the density of the fires and the difficulty of extinguishing the fires [2].

Indonesia is a country that has the largest peatlands. The area of peatland in Indonesia is around 21 million ha spread across Sumatra, Kalimantan, and Papua [3] where only about 6 million ha are suitable for agriculture. Parish et al. (2007) stated that peatlands have a function as carbon sinks that contribute to reducing greenhouse gases in the atmosphere even though the tethering process is very slow, namely only as high as 0-3 mm of peat per year [4], [5], [6]. If peat forest is cut down and drained, the carbon stored in the peat will be easily oxidized to $\mathrm{CO}^{2}$ gas. Besides, clearing peatlands will cause subsidence. Therefore, careful planning and care are needed in the conversion of peat forests.

Peatland ecosystems are very important in the hydrological system of the downstream area of a 
watershed (DAS). This is because the peatland ecosystem can absorb water up to 13 times its weight. Peat areas are also a very large store of carbon stocks, both above and below the ground. Damage to the peat ecosystem will have a major impact on the local environment (in situ) and the surrounding environment (ex situ). For example, the occurrence of flooding in the downstream watershed is one of the impacts of the destruction of the peat ecosystem. Forest and peatland fires can also cause $\mathrm{CO}_{2}$ emissions to be very high so that it will disrupt public health due to shortness of breath such as ISPA. The problem formulation in this article focuses on environmental health in communities around peatlands.

\section{Literature Review}

Environmental health problems are problems that are actually created by the community itself and can only be handled by the community. It is relatively easy to get individuals to take action when it comes to individual health issues. However, the new challenge is how to get the whole community to act, not only for the benefit of the individual but also for the benefit of society as a whole. Therefore, Clay and Basset (2004) created a new vision of environmental health which states that there is a need for interdependence between the social, economic, and environmental aspects of human activity which calls for an improvement in the quality of life in the future through cooperation and partnerships.

The development of environmental health science continues. This is shown by the results of research conducted by [7] which modified the imaginative vision of Clay and Bassett (2004) by putting four aspects of environmental health into a mutually supportive unit. These aspects include (1) changes in clinical outcomes, (2) changes in economic outcomes, (3) changes in environmental exposures, and (4) changes in population outcomes. These four aspects are then used as a basis for determination in clinical practice, public health practice, individual behavior, policy, risk management, and practical research.

\section{Research Method}

The research was conducted in Kepenghuluan Bagan Sinembah Timur, Bagan Sinembah Raya Sub District, Rokan Hilir Regency. The object of the research was the community living on peatlands and stakeholders (Penghulu/Village Head, Village Secretary, and Village Midwives). The research method used was qualitative where data collection was done through interviews, observation, and documentation. The data obtained in the field were always narrated in the form of transcript text. Miles and Huberman [8] and Hamzah [9] stated that there is three flow of activities that must be carried out in data analysis, continuously until the data obtained are saturated, namely: Data reduction, data presentation, and conclusion/verification.

\section{Findings and Discussion}

Kepenghuluan Bagan Sinembah Timur is an area dominated by peat which covers $89.92 \%$ where the rest $(10.08 \%)$ is mineral soil [10]. The oil palm plantations are the main commodity of the community. This is because people think only oil palm can live on peatlands. The peatlands in Bagan Sinembah Timur are dominated by shrubs in the form of ferns that have not been managed by the community. Apart from the difficult access or position of the land, the inadequate use of peatlands is also influenced by the depth of the peat, which in the rainy season, most of the peat which is overgrown with shrubs will be flooded so that people are reluctant to manage it. Based on the information the researchers got, it is known that the management of peatlands for oil palm plantations requires a very large amount of funds. For people who do not have sufficient funds, the land will be left empty.

Based on the results of the mapping, it was found that more than 3000 hectares or about $38 \%$ of the Kepenghuluan Bagan Sinembah Timur area consists of peatland overgrown with shrubs in the form of ferns. This land has not been used or managed by the community. This condition requires program intervention in utilizing peatland which is expected to have an impact on economic improvement but still using the principle of sustainability. The current concern of the community is that if the land is not utilized, then during the dry season, it will be prone to fires and flooding in the rainy season.

Judging from the use/utilization of the Kepenghuluan Bagan Sinembah Timur land, it is known that most or around $61.40 \%(6,370,020 \mathrm{Ha})$ are used for the oil palm plantation sector, both community-owned oil palm plantations and large-scale companies over hundreds of hectares. This condition illustrates that the biggest livelihoods of the people in Kepenghuluan Bagan Sinembah Timur are in the agricultural/oil palm plantation sectors, such as farmers and oil palm labor. The rest are engaged in the procurement of goods and services such as traders, teachers, village government, breeders, and vegetable farmers. The community only thinks about the economic and social aspects but does not think about the health and environmental aspects that arise from the impact of peatland use. To protect peatland from damage, it must be managed sustainably. Sustainability in this 
case is to improve the welfare of the present generation without reducing the possibility of the welfare of future generations. This means that in the management or use of peatlands, we must pay attention to the impacts, both on the environment and public health.

The peatland management strategy in each area will vary according to the situation and local characteristics, in which elements or values and norms will be included. These values and norms constitute the local wisdom of the local community in interpreting and managing natural resources and the environment. In Kepenghuluan Bagan Sinembah Timur, the community uses peatland for oil palm plantations using the 212 methods. This method means that for every two rows of palm trees, there will be one canal. This method serves to drain the land so that it can be planted. Creating drainage or canals to protect water in peatlands without draining it into rivers [11]. In long-term use, this method harms the peat ecosystem if the canals are drained into rivers.

Referring to the results of interviews and observations conducted by researchers, it was found that the rainy season caused residents' gardens and community settlements to be submerged. The inundation of people's gardens is caused by the peat which has lost its function as water retention. In the end, this will make it difficult for the community to carry out activities on their land. Researchers also found that some communities living on peatlands have simple toilets, while the rest do not have latrines at all, and do not have a source of clean water. For people who do not have a latrine, the need to defecate is carried out behind the house by digging a hole and then filling it again.

The next finding is that the community fulfills the need for bathing and washing by using peat water in the canal around the house. When the flood season comes, the waste in the form of human and livestock manure will be scattered and cause a bad smell and pollute the peat water. This condition is already considered normal by the community where they also do not realize that this condition will increase their risk of exposure to disease in the future. One of the diseases that arise after flooding is usually itching of the skin. According to them, this disease will heal by itself without having to take serious treatment.

This is categorized as herd immunity, which means an attempt to stop the rate of spread of the virus naturally by the body so that the body's immunity will appear and the virus subsides by itself [12]. The next finding was that during the dry season, the concern felt by the people living in peatlands was a fire. The impact of peatland fires for them is the appearance of smoke, causing shortness of breath or ISPA. This condition worsens the health of residents. Unfortunately, community awareness about the destruction of the peatlands around them is minimal. ARI as an environmentally based disease is a disease that threatens residents every dry season. Lung dysfunction and acute headaches can cause fainting and death [13].
Itching and ARI are environmental based diseases caused by poor sanitation and the environment. This is one of the main focuses of environmental health. It is hoped that the quality of life of the people on peatlands will increase as their awareness of environmental health is high. Clay and Basset [6] explained that an important aspect of environmental health is human health related to the quality of life where the determining factors, in this case, are physical, biological, social, and psycho-social in an environment. It refers to the theory and practice of assessing, correcting, and preventing environmental factors that have the potential to affect public health in the future.

Blum [14] described four factors that influence public health status, which include behavioral or lifestyle factors, environmental factors, health-care factors, and genetic factors. Of the four factors, environmental factors are the most dominant determinants that affect public health as well as the most difficult to overcome. Society is more concerned with economic aspects than health and the environment. Behavioral factors, in this case, must also be considered, such as lifestyle and human actions that have the potential to damage the environment. If the environment is not maintained properly, it will cause various diseases. To control disease based on the environment, it is necessary to know the course of the disease or the pathogenesis of the disease, so that we can intervene quickly and precisely. Then the way to prevent the impact on the environment is also by streamlining the regulation of various environmental sources so that it can improve the health, welfare of human life, and prevent the dangers of disease [15].

The principles of environmental health developed by Clay and Basset (2004) consist of six factors, which include: [1] Maintenance and improvement of the welfare of human life that comes from the environment. Communities on peatlands need education and health promotion to increase their understanding and knowledge of environmental health. With this increased understanding and knowledge, it is hoped that their future welfare on peatlands will also increase and that they live side by side with peatlands more easily, [2] Marginalized groups of people who live in bad environments, be it economic, social, environmental, and health. This requires efforts and actions from related parties to save these community groups. Every effort and action will be successful if the main elements of environmental health are implemented, namely: Justice for marginalized communities [3] and effective environmental health governance requires a just democracy. So far, the programs that the community has received have only been limited to providing programs, without any assistance to the people who were assisted. This causes the program to just end when the activities are completed, without any sustainability. However, government programs that enter after 2019 are related to peatlands in Kepenghuluan Bagan Sinembah Timur. In this program, sustainability is always considered after 
the program ends. [4] The existence of cooperation and partnerships in efforts to improve environmental health, not only between the health and environmental sectors but also with the economic sector and with all social partners. These are principles that are at the heart of effective environmental health management. The partnership that was included in Kepenghuluan Bagan Sinembah Timur was found to only focus on environmental, social, and economic aspects. This program is carried out by government agencies such as the Peatland Restoration Agency with funding from the Partnership (Partnership) through Deputy III of BRG, which focuses on community empowerment, particularly the environment, social, and economy, [5] The idea of sustainable development and sustainability is closely related to sustainable effective management as reflected by the existence of integrated policies, partnerships, and at an appropriate scale to achieve sustainable development. Sustainability is evidenced by the inclusion of a peatland management program in the Village Government Work Plan (RKPDes) of Kepenghuluan Bagan Timur every year and [6] Environmental health issues are a world issue, but there are very few people who protect human welfare compared to humans who protect their personal and group interests. Ideally, protecting human well-being is a major factor in environmental health. However, in reality, there are also some non-governmental organizations and village government officials who are involved in destroying peatlands for personal gain.

If the six principles of environmental health put forward by Clay and Basset (2004) are fulfilled, the quality of life for people on peatlands can improve as a whole. Based on the above analysis, the researcher then makes a synthesis of his findings related to environmental health as follows: (a) Health Aspects. Knowing the findings in

\section{Social}

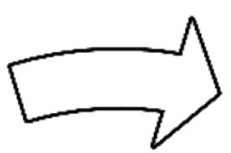

\section{Economic}
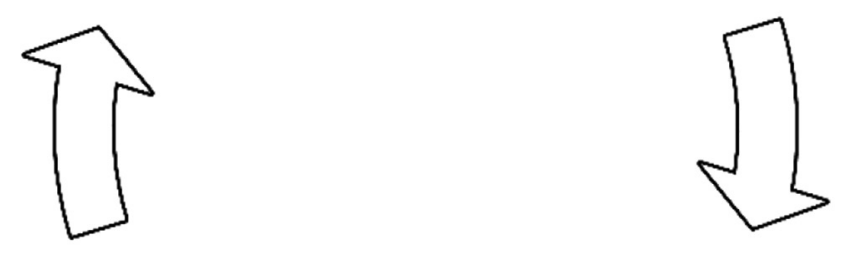

\section{Environmental}

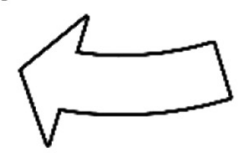

Figure 1: Environmental health vision (Source: Synthesis Researcher, 2020) the field, the researchers concluded that people living in peatlands have a low understanding and knowledge of health aspects, especially sanitation. The low level of understanding and knowledge is caused by the behavior of the community itself and the absence of health education and promotion from the government. Government programs are included in the Kepenghuluan Bagas Sinembah Timur only focus on environmental, social, and economic aspects, (b) Environmental Aspects. Based on the findings in the field, the researchers concluded that people living in peatlands have a fairly high understanding and knowledge of the environmental aspects of peatlands. This understanding and knowledge were obtained from the existence of a government program that was included in the Kepenghuluan Bagan Sinembah Timur which discussed management and how to maintain ecosystems in peatlands, (c) Social Aspects. Knowing the findings in the field, the researchers concluded that people living in peatlands have a fairly high understanding and knowledge of the social aspects of peatlands. This understanding and knowledge were obtained from a government program that entered Kepenghuluan Bagan Sinembah Timur through cooperation activities. This cooperation activity evokes enthusiasm and community togetherness in managing and maintaining ecosystems on peatlands, and (d) Economic Aspects. Knowing the findings in the field, the researchers concluded that people in peatlands have the highest understanding and knowledge of the economic aspects of peatlands compared to the three previous aspects. This understanding and knowledge were obtained from a government program that was included in the Kepenghuluan Bagan Sinembah Timur, namely, in the form of a program to increase economic welfare. The community is very enthusiastic about participating in government programs related to the economy and welfare.

Based on the above synthesis, the researcher created a new vision by modifying the imaginative vision of Clay and Basset (2004) and the environmental health research framework developed by [7]. The new environmental health vision is to interactenvironmentally, socially, and economically to improve public health toward better quality. The following (Figure 1) is a new vision created by researchers:

In its development, environmental health is classified as a multidisciplinary science that discusses the dynamics of interactive relationships between individuals, groups, and communities to environmental changes that affect the quality of life of the community. In line with environmental health, the interactivity of individuals, groups, and communities toward environmental changes affects the quality of life of the community. This is following the healthy living paradigm so that it can be called the environmental health paradigm. To implement the environmental health paradigm, environmental health literacy is needed as a medium for understanding and analyzing information related to environmental health, especially 
for communities on peatlands to achieve an improved quality of life and environmental protection on peatlands.

\section{Conclusion}

Kepenghuluan Bagan Sinembah Timur is an area that is dominated by peat. The oil palm plantations are the main commodity of the local community. This is because people think only oil palm plants can live on peatlands. To protect peatlands from damage, sustainable peatland management needs to be applied. Environmental health problems in Kepenghuluan Bagan Sinembah Timur arise due to the destruction of peatlands and the low awareness of local communities, as well as their understanding and knowledge. The new environmental health vision developed by researchers is to integrate the environment, social, and economy to improve public health toward better quality. In its development, environmental health is classified as a multidisciplinary science that discusses the dynamics of interactive relationships between individuals, groups, and communities with environmental changes that will gradually affect the quality of life of the community. In line with environmental health, interactivity between individuals, groups, and communities with environmental changes also affects the quality of life of the community. This is following the healthy living paradigm so that it can be referred to as the environmental health paradigm. To implement the environmental health paradigm, environmental health literacy as a medium for understanding and analyzing information related to environmental health is needed, especially for people living on peatlands. Through these efforts, it is hoped that improvement of life quality and environmental protection on peatlands can be achieved.

\section{Acknowledgment}

Researchers would like to thank Penghulu Bagan Sinembah Timur, Village Secretary, Village Midwives, enumerators, and the community who have helped researchers a lot in gathering information for this research.

\section{References}

1. Miller MD, Valenti M, Schettler T, Tencza B. A multimedia e-book-a story of health: Filling a gap in environmental health literacy for health professionals. Environ Health Perspect. 2016;124:A133-6. https://doi.org/10.1289/ehp222 PMid:27479986

2. Purnomo H, Shantiko B, Sitorus S, Gunawan H, Achdiawan R, Kartodihardjo $\mathrm{H}$, et al. Fire economy and actor network of forest and land fires in Indonesia. For Policy Econ. 2017;78:21-31. https://doi.org/10.1016/j.forpol.2017.01.001

3. BB Litbang SDLP. Balai Besar Penelitian dan Pengembangan Sumberdaya Lahan Pertanian. Laporan Tahunan 2008, Konsorsium Penelitian dan Pengembangan Perubahan Iklim Pada Sektor Pertanian. Balai Besar Penelitian dan Pengembangan Sumberdaya Lahan Pertanian, Bogor; 2008. https://doi.org/10.5994/jei.11.1.43

4. Parish FA, Sirin D, Charman H, Joosten T, Minayeva M, Silvius $\mathrm{M}$, et al. Assessment on Peatlands, Biodiversity and Climate Change: Main Report. Wageningen: Global Environment Centre, Kuala Lumpur and Wetlands International; 2007.

5. Agus F. Cadangan Karbon, Emisi Gas Rumah Kaca dan Konservasi Lahan Gambut. Prosiding Seminar Dies Natalis Universitas Brawidjaya Ke 46, Malang; 2009.

6. Clay H, Basset WH. Clay's Handbook of Environmental Health London, United Kingdom: Spon Press; 2004.

7. Pettibone $\mathrm{KG}$, Balshaw DM, Dilworth $\mathrm{C}$, Drew $\mathrm{CH}$, Hall JE, Heacock $M$, et al. Expanding the concept of translational research: Making a place for environmental health sciences. Environ Health Perspect. 2018;126(7):074501. https://doi. org/10.1289/ehp3657

PMid:30024381

8. Miles MB, Huberman AM. Qualitative Data Analysis. $2^{\text {nd }}$ ed. California: SAGE Pulication Inc.; 1984.

9. Hamzah A. Metode Penelitian and Pengembangan (Researtch and Development) Uji Produk Kuantitatif dan Kualitatif Proses dan Hasil Dilengkapi Contoh Proposal Pengembangan Desain Uji Kualitatif dan Kuantitatif, Literasi Nusantara; 2019. https:// doi.org/10.31227/osf.io/4nq5e

10. BRG. Badan Restorasi Gambut. Kemitraan Partnership. Governance Reform in Indonesia; 2019.

11. Irfan A, Febria D, Nofianti L, Rijulvita S. The conceptual framework for water accounting in sustainability of peatland ecosystems. An Islamic perspective. J Environ Manag Tour. 2020;11(3):589-93. https://doi.org/10.14505//jemt.v11.3(43).11

12. Darmawan A. Epidemiologi penyakit menular dan penyakit tidak menular. JAMBI Med J. 2016;4(2). https://doi.org/10.31219/osf. io/qz8fb

13. Uda SK, Hein L, Sumarga I. Towards sustainable management of Indonesian tropical. Peatl Wetl Ecol Manage. 2017;25(6):683-701. https://doi.org/10.1007/s11273-017-9544-0

14. Blum HL. Planning for Health, Development and Aplication of Social Changes Theory. New York: Human Sciences Press; 1974.

15. Ikhtiar M. Pengantar Kesehatan Lingkungan. Indonesia: Penerbit CV, Social Politic Genius (SIGn); 2017. 